\title{
AC 2007-1309: IDENTIFYING IMPROVEMENT OPPORTUNITIES IN THE HIGH SCHOOL-COLLEGE BRIDGE FOR ENGINEERING STUDENTS: A FOCUS GROUP APPROACH
}

\section{Valerie Galarza, University of Puerto Rico-Mayaguez}

Valerie Galarza is a 4th year Industrial Engineering student at the UPRM participating in an undergraduate research opportunities program related to engineering education. Valerie is an officer of the Institute of Industrial Engineers student chapter and INFORMS.

\section{Mariela Figueroa, UPRMUniversity of Puerto Rico-Mayaguez}

Mariela Figueroa is a 4th year Industrial Engineering student at the UPRM participating in an undergraduate research opportunities program related to engineering education. Mariela is an officer of the Institute of Industrial Engineers student chapter and INFORMS.

\section{Cristina Lugo, University of Puerto Rico-Mayaguez}

Cristina Lugo is a 4th year Industrial Engineering student at the UPRM participating in an undergraduate research opportunities program related to engineering education. Cristina is an officer of the Institute of Industrial Engineers student chapter and INFORMS.

\section{Ricardo Rodriguez, University of Puerto Rico-Mayaguez}

Ricardo Rodriguez is a 4th year Industrial Engineering student at the UPRM participating in an undergraduate research opportunities program related to engineering education. Ricardo is an officer of the Institute of Industrial Engineers student chapter and INFORMS.

\section{Francisco Rivera, University of Puerto Rico-Mayaguez}

Francisco Rivera is a 4th year Industrial Engineering student at the UPRM participating in an undergraduate research opportunities program related to engineering education. Francisco is current President of the Institute of Industrial Engineers student chapter, SHPE and INFORMS.

\section{Alexandra Medina-Borja, University of Puerto Rico-Mayaguez}

Dr. Alexandra Medina-Borja is an assistant professor at the University of Puerto Rico at Mayaguez and Director of the International Service Systems Engineering Lab. Alexandra holds a Masters and Ph.D. degrees from Virginia Tech in Industrial and Systems Engineering. Alexandra holds an undergraduate degree in Production of Materials Engineering from the Federal University of Sao Carlos, in Sao Paulo, Brazil. Her research interests are systems thinking, systems dynamics, service operations, performance measurement using DEA, evaluating success factors in engineering and the cognitive processes that occur during its acquisition. 


\title{
IDENTIFYING IMPROVEMENT OPPORTUNITIES IN THE HIGH SCHOOL - College Bridge for Engineering Students: A Focus Group APPROACH
}

\begin{abstract}
The educational pre-college background of entering freshmen has been defined as a decisive predictor of college success in STEM disciplines. It is then important to develop an understanding of the factors that affect the level of preparation of students entering engineering. We present the results of a series of focus groups undertook to elicit high school deficiencies and other problems faced by engineering students upon arrival to college in the opinion of current industrial engineering students at the University of Puerto Rico at Mayaguiez. We aim to define areas of opportunity to develop tools and workshops to train high school STEM teachers for a future phase of this project. Differences among different types of high school characteristics in the island are being controlled, such as main language of instruction, whether the HS is private or public and their geographic location. The focus groups were conducted by undergraduate students that are part of an undergraduate research opportunities program in the IE department. Students exposed the mistakes and good practices of their high school teachers that resulted in knowledge gaps or helped them achieving success once in college. Partnerships among government and academia could be formed to take corrective action and improve HS preparation so that the college experience and subsequent retention into engineering fields is improved.
\end{abstract}

\section{I- INTRODUCTION}

The importance of educating well-prepared engineers is undeniable because of its implications to our twenty first century global society. At the same time, the increasing loss of students who start studying engineering and then change to other major or drop out of college is high $^{1,2,7}$. In the search for possible reasons for this desertion researchers have found that HS preparation is essential for college success into engineering fields. It has been demonstrated that it plays an important role in student's achievements during their college experience ${ }^{5}$. Even though other researches who have studied this topic ${ }^{2}$ have concluded that High School instruction isn't enough to prepare engineering students to university's level courses, we believe it is a crucial factor.

At the University of Puerto Rico at Mayagüez, UPRM, attraction into engineering fields is not a problem, since applications from the best HS students in the island --both female and male-- have been steadily growing. The problem faced by most engineering departments is in fact the time that these supposedly brilliant students are taking to graduate. Normally a five year program of 175 credits, most students take an average of 5.5 years to complete the coursework, with ranges from 4.5 to 8 years. For this reason it is imperative to identify which of the factors that are affecting the academic life of those engineering students that prevent them to progress in their coursework, can be categorized as deficiencies of their HS educational preparation. It is also important to identify the academic difficulties faced during the early years of the college 
experience to look for improvement opportunities, and to take corrective action. The overall goal is to increase the retention and college success of students into engineering careers.

We present the results of a series of focus groups undertook to elicit the high school deficiencies and other problems faced by pre-college students that are evident once they are admitted into engineering, in the opinion of current industrial engineering students at the University of Puerto Rico at Mayagüez, UPRM. Attraction into engineering careers is not a problem at all at the UPRM. At the UPRM we want to create a stronger network between government and the Department of Education of Puerto Rico to improve the educational system in the areas that constitute a gap once freshmen -who had high-self efficacy beliefs in high school-- enter engineering to face a rigorous math and science program and leave engineering due to attrition or beliefs of lack of adequacy for the career.

Our objective with this research is to search what are the deficiencies in HS preparation to identify improvement opportunities so that to enhance the college experience of our students and improve attrition.

In the next section we will review the main factors that appear in the literature as critical for freshmen success and subsequent retention.

\section{II- LiterATURE REVIEW}

\section{A. Critical and Non-Critical Factors in Freshman Enrollment}

Heckel $^{1}$ presented some high school factors that can influence the selection of engineering as a career. This author considers the trends in engineering enrollments and graduation in engineering, and makes comparisons between total freshmen enrollments and bachelor degrees over several decades. According to Heckel, one factor that may play a significant role in selecting engineering as a career is financial gain. Economic factors such as variation in numbers of career opportunities, national economic trends, rates of growth of starting salaries and the difference between engineering and other career starting salaries can affect positively or negatively the selection of engineering as a career. However, studies throughout years show that there is not correlation between the national economic conditions and the enrollments of freshman in engineering.

This study also shows that students appear to enroll in engineering with many expectations and a priori perceptions, like the individual economic reward and many others, but they don't establish their priorities, forgetting their personal interests. This causes many difficulties in all the progression of the academic life ${ }^{1}$. Some professors or parents should try to accommodate the expectations of students through appropriate curriculum or personal mentoring, helping students in the selection of choices. 


\section{B. Attrition}

It is a fact that less than half of freshmen engineering students in the US fail to stay studying engineering. The attrition is generated from a wide branch of possibilities. Though different answers become evident, there are some that have been proven to be true. Success will depend on knowledge and skills but the attitudes assumed by the students, attitudes they bring with them to college, will play an equally important role.

A three year study of students in college ${ }^{2}$, classifying them as those who left engineering in good academic standing, those that left in bad academic standing and those who stayed back in engineering had interesting findings. Student attitudes were identified in freshmen, as well as their perceptions about their educational experience and the level of confidence in their ability to succeed in engineering. Students that left school in good academic standing were significantly different in attitude than the ones who left the school in poor academic standing. The ones in good academic standing usually move to other concentrations and usually have a successful nonengineering career further, and those who dropped out of college in poor academic standing did not usually followed other study options at all.

\section{Intellectual Development - Critical thinking}

Felder and Brent ${ }^{3}$ established that intellectual inquiry and endorsement of the selfresponsibility to learn are the two characteristics that determine an optimal model of how engineers and scientists learn. Therefore, attainment of those students characteristics are a high level goal but one that would guarantee success in college for engineering students. Therefore, universities can promote intellectual development to help science and engineering departments so that their students develop the necessary intellectual capacity. During recent years, society has recognized the importance of critical thinking for the intellectual development of college students. This paper states that students can leave behind superficial learning to open the road of analytic, creative, and deep learning. These are the steps where one can reach such intellectual development. It proposes an educational model to reach this goal. The educational model consists of synthesis, of variety and choice of learning tasks; explicit communication and explanation of expectations; modeling, practice, and constructive feedback on high-level tasks; a student-centered instructional environment and respect for students at all levels of development. Unfortunately, most science and engineering students enter college at low levels of critical thinking, and when they are taught they generally graduate at levels not much higher than those at which they entered. This is the reason for which this educational model has been built, to fight this huge intellectual lag in entering college students and to help instructors educate better professionals in science and engineering.

\section{Promoting Students Success}

Marna Zinatelli and Marc A. Dubé wrote in an article title "Engineering Student Success: How Does it Happen and who is Responsible?" about strategies that reach the academic performance in engineering students. Information that they found tells that study skill training plays an important role and result in a better academic performance in students, but it is limited. It is necessary that educational institutions increase the accessibility of this resource. They found 
that HS teacher can help in this goal by helping students how to learn and motivating them to change their study habits.

Some recommendations that Zinatelli and Dubé made in this paper is that to "reach an academic performance is necessary that students recognize the benefits of changing the way they study by motivating them to participate of study skills training". They found that students change their behavior by stage. For this reason professors can influence them to move from one stage to another by giving advice to motivate them to change, removing barriers by making service easier to access, giving them different alternatives to study, aware students about the negative consequence of not change, external pressure, giving personal feedback, establish a goal setting by increasing the sturdy hours, and helping in a desired attitude (the most important of all for motivating change) $)^{4}$.

\section{E. Dragging Out Graduation}

A longitudinal research ${ }^{5}$ study of nine institutions from 1987 through 2002 used a database of all engineering students focused on graduation in any of the engineering disciplines. They were interested in the statistical relationship between the predictors of graduation in engineering and modeled graduation versus predictors along multiple logistic curves. A multiple logistic regression model was fitted to each institution's data to explore the relationship between graduation, demographics and academic characteristics. The study found several factors that have a significant effect on graduation rates in engineering for entering students. These factors are high school GPA, math SAT scores, gender, ethnicity and citizenship. These researchers found that HS GPA and math SAT scores were positively correlated with graduation rates and that verbal SAT scores were negatively correlated with odds of graduation. Gender, citizenship and ethnicity showed significant effects either positive or negative.

They also studied the graduation rates of males and females and found that women who matriculate in engineering graduate in engineering at the same rate as men. They also found that the choices students make after enrollment affect students success significantly. From this analysis they were able to infer the probability of graduation as a function of each predictor. Researchers are in the process of expanding the scope of the succeed Longitudinal Base to create the Multiple-Institution Data Base for Investigating Engineering Longitudinal Development ${ }^{5}$.

In conclusion, there are several factors influencing students' achievement in their engineering discipline. Educational background is been identifying as a determinant factor to reach a success career. Concerns about weaknesses in HS education that limit students success in the initial years of study in an engineering school, have generated research interest. Several studies have been undertaken at the University of Puerto Rico at Mayagüez around this subject, utilizing different methods of data collection like, surveys, professor's observations, data inferences and statistics, but no one has used a focus group approach. The next section briefly describes de methodology used. 


\section{Methodology AND Data Collection}

Focus group is a methodology that allows the participant to voice his/her opinions and concerns in an open-ended semi-structured manner providing light to nuances and aspects of the issue at hand that no other data collection method can. Focus groups have been used in the past to evaluate engineering programs and to elicit student characteristics ${ }^{7}$.

Based in the seminal work of Richard Krueger's book ${ }^{8}$, design, execution, and analysis of the study took place over one academic (fall) semester, decision-making and follow-up reporting took place over the following month in spring.

Supported on the study objectives and target audience, the research advisor and moderator students determined the types of groups needed. Homogeneity within the groups was established as a necessary feature of focus groups and it was obtained based on ten characteristics to categorize showed in Table 1.

\begin{tabular}{|l|l|}
\hline \multirow{2}{*}{ TABLE 1: FOCUS GROUPS CONTROL VARIABLES } \\
\hline \multirow{2}{*}{ Industry Experience } & Male \\
\cline { 2 - 2 } & Female \\
\hline \multirow{2}{*}{ Type of School } & Internship \\
\cline { 2 - 2 } & Coop \\
\hline \multirow{3}{*}{ School Language Focus } & Public \\
\cline { 2 - 2 } & Private \\
\hline \multirow{2}{*}{ Transfer } & English \\
\cline { 2 - 2 } & Spanish \\
\cline { 2 - 2 } Geographic Area of School Location & Bilingual \\
\hline \multirow{2}{*}{ Level of Academic Difficulty Faced } & Transferred from another campus \\
\hline Math Preparatory Courses & Rural Zone \\
\hline \multirow{2}{*}{ Class Level } & Pre-Basic Calculus \\
\hline & Wrademic Difficulties --More than six years for \\
& Freshman \\
\cline { 2 - 2 } & Second to fifth year student \\
\hline
\end{tabular}

After the arrangement of these features twelve types of homogeneous groups of approximately 5-8 students were formed and is illustrated in the next flowchart in Figure 1. 


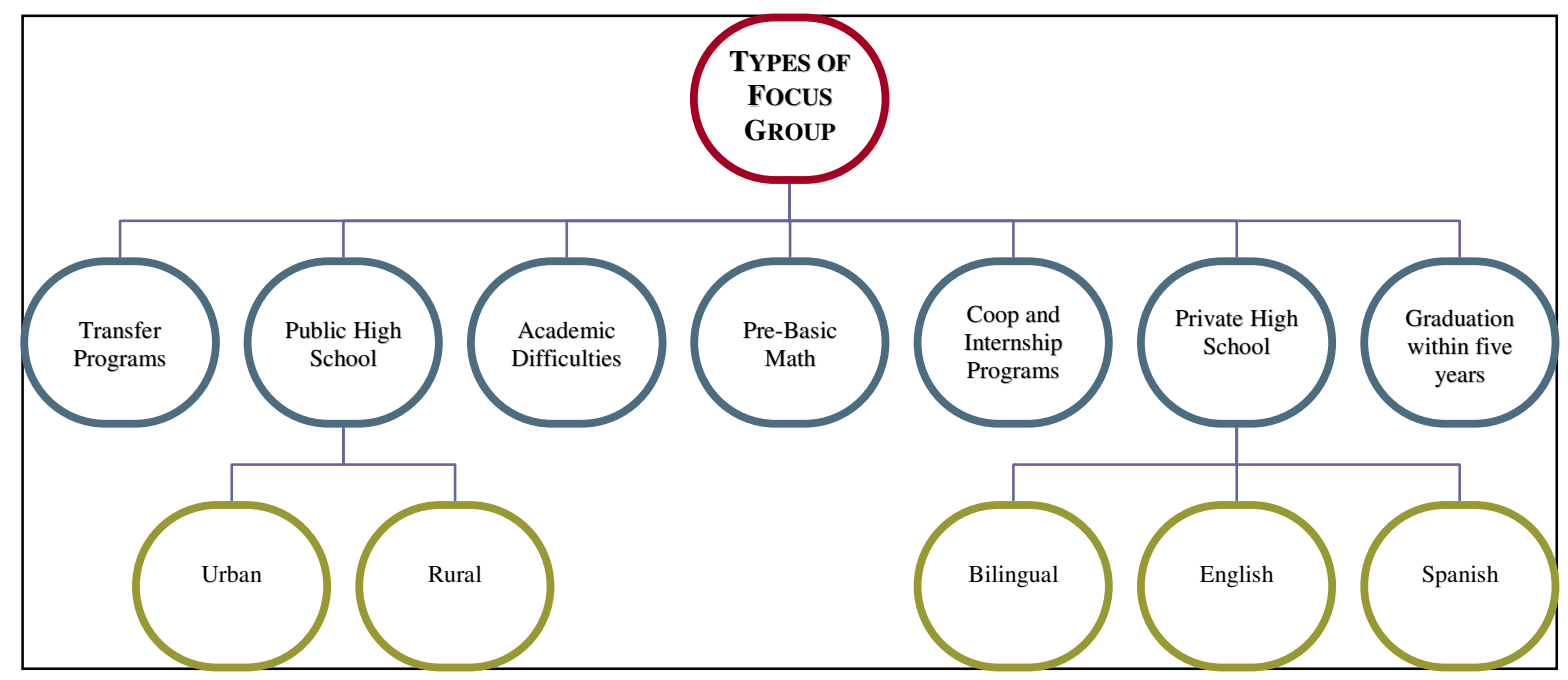

Forty five students participated in this project. Twenty three were females and twenty two males, all of them were undergraduate students ranging from the freshmen to the fifth-plus year.

Students were asked to complete a questionnaire regarding demographic and high school related factors, such as the type of high school they attended, the language of instruction (English or Spanish or bilingual), year of admittance and expected year of graduation and other questions regarding their level of math and English in preparatory courses in the first semester. Nine focus groups were conducted controlling for different factors, the selection was made by these questionnaires.

Moderators were previously selected from Industrial Engineering students enrolled in third to fifth year and who are participating in an undergraduate research opportunities program. They were instructed in focus groups techniques as described in $^{7,8}$ and were instrumental in the development of the script. They conducted several design meetings with their research advisor and developed the script so that students will feel acknowledged and understood. Discussions regarding Puerto Rican student culture and other important issues were hold. They established the themes, questions and time table activities.

One focus group session was executed for each of the twelve types of groups. Pizza was the incentive to attract students for meetings. For each group session, a moderator and a recorder were assigned. No individual names were said during the recording process. Once all groups sessions finished, tapes transcription were made and became the basis for data analysis.

Script topics were divided in seven parts. The topics are depicted in Figure 2. 


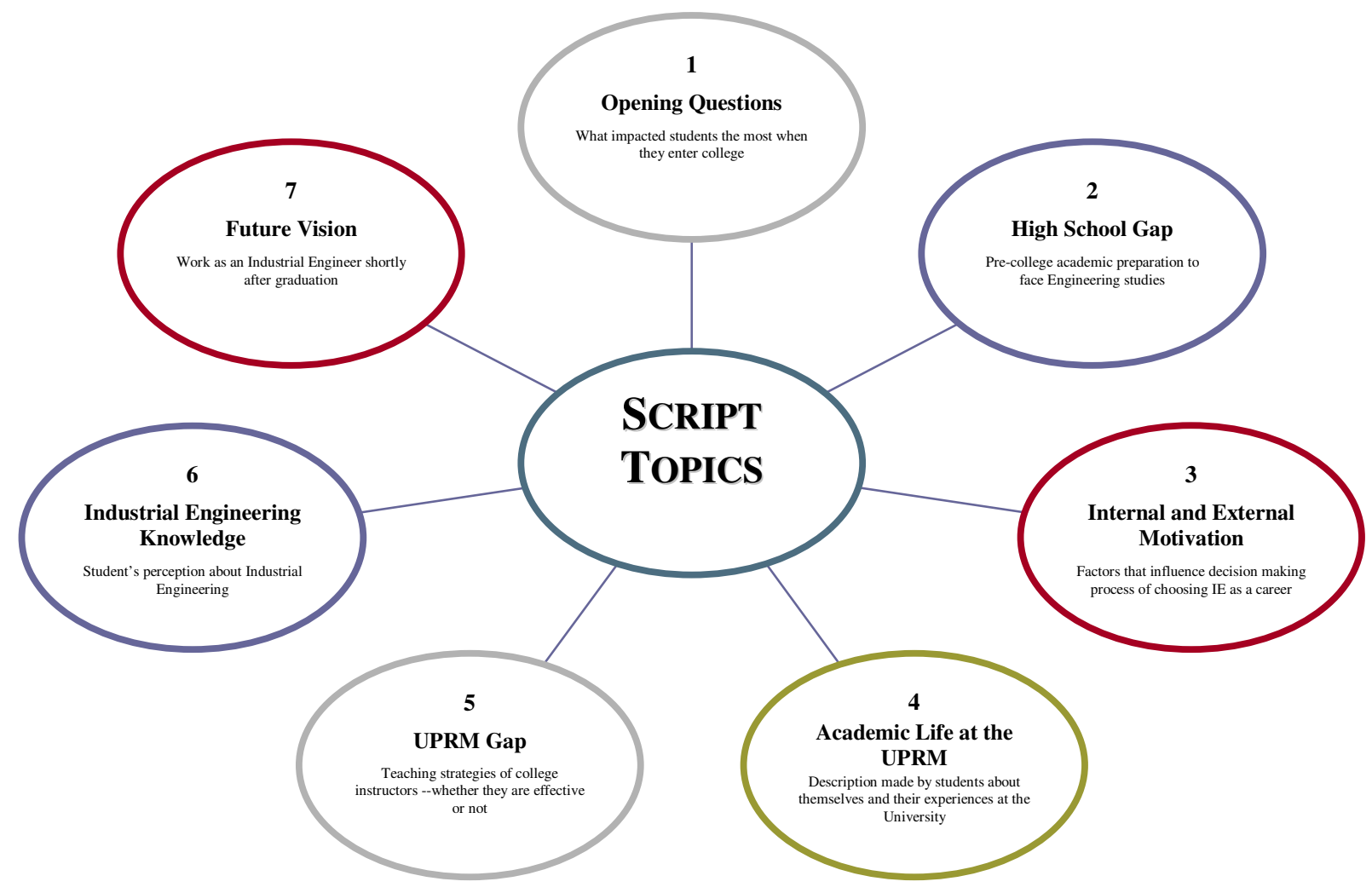

Each topic was assigned to a group of students for further analysis and reporting. A different paper was created based on each topic and differentiated findings. The results of this study will inform a more comprehensive initiative of high school outreach, and the involvement of math and science teachers in the success of engineering students.

\section{ANALYSIS AND ReSUlts}

After completing the focus groups, the moderators (undergraduate student researchers) and their research advisor brainstormed, selected and classified relevant topics of high school experience and preparation that were deemed important to reach engineering student success. The objective was to identify improvement opportunities in secondary education institutions.

It is important to mention that as of today, industrial engineering at the UPRM has a remedial approach aimed at granting admission to good students with varied pre-college preparation backgrounds. The process of allocating students to specific math courses once they enter industrial engineering varies a lot. There are four kinds of classifications which are the following: Pre basic, Pre-calculus, Pre-calculus/Calculus and Calculus. Students which successfully passed Pre-calculus at High School need to take and approved a final exam (with a score of 5 out of 5) from the College Board, once this is accomplished, the General College Board scores on math are also analyzed (at least 650 out of 800) in order to be placed in advanced courses (Calculus I) in the first year of college. Students whom got 4 out of 5 in the final Pre-calculus exam from the College Board and had a score of over 650 in math in the General College Board are placed in Pre-Calculus/Calculus. On the other hand, students who did 
not have the opportunity of taking advance courses (Pre-calculus) in High School but scored over 650 on the General College Board in math are positioned in Pre-calculus. Finally, those students that did not accomplished the 650 score needed to take an exam before their start of classes in college, those who fail start math courses in Pre-basic and those who pass are placed in Precalculus.

In the course of the analysis, data were divided by relevant arguments exposed with some frequency. Major themes or categories discussed by focus group participants included impact of their new college life in the freshmen year, academic difficulties faced immediately after admission, HS preparation, improvements needed in their HS of origin, lack of abilities, path to get admission to college, mathematical skills and favorite courses. The mentioned categories are discussed in the following sections and all graphs are based on student answers during the focus groups. Table 2 shows the main themes found.

\section{IMPACT Felt ARriving to College}

The major impact during their transition from High School to engineering school expressed by industrial engineering student were by large the change of environment. The group that showed more difficulties adapting to the university's environment are the ones that come transferred from other programs of the UPR system, even though they tend to perform well academically speaking; however this is not a trend for those who came from public or private school directly. An answer that was frequently argued by students in the transfer program category, "There (in the university of origin), professors were more attentive with you, here they aren't, you can have a problem and you are on your own" is one of the many critics students told.

Other aspects affecting entering students are the criticism against faculty and their attitudes when teaching, particularly those teaching courses in the first and second semester after admission. These feelings are to be expected since these students were in a friendly and closed environment with their professors. A reason for this difference might be the kind of college they came from, one that is considerably smaller than ours.

In addition, students that came from public and private schools have a difficult adjustment to their professors and adaptation to independent lives, including some distractions. In general, some of those factors are caused by a new stage in their lives far from their hometowns, in a transition of dependent to independent life. A transition that is much different from American students since Puerto Rican culture fosters a very strong dependent link among families. College students do not need to leave home. A large percentage of engineering students try to travel back to their hometowns every weekend while away (with a maximum driving time of 3.5 hours). To be away from their parents was difficult for many students and they expressed it a lot.

Other impact shown on those students was the poor instruction they perceived they received in HS. Math deficiencies, poor study habits and poor teaching strategies were some of the problems that students presented, and contrary to our initial hypothesis, the kind or location of the school had no impact, whereas public or private, rural or urban. Mainly, students complained about bad academic teaching strategies in high school. There are strategies that did 
not at all prepare them for an engineering field. HS teachers are using a curriculum that doesn't bring the necessary tools and knowledge in the areas of math and science. It is important to provide a wide curriculum with a specialization in those areas, to achieve engineering student's success.

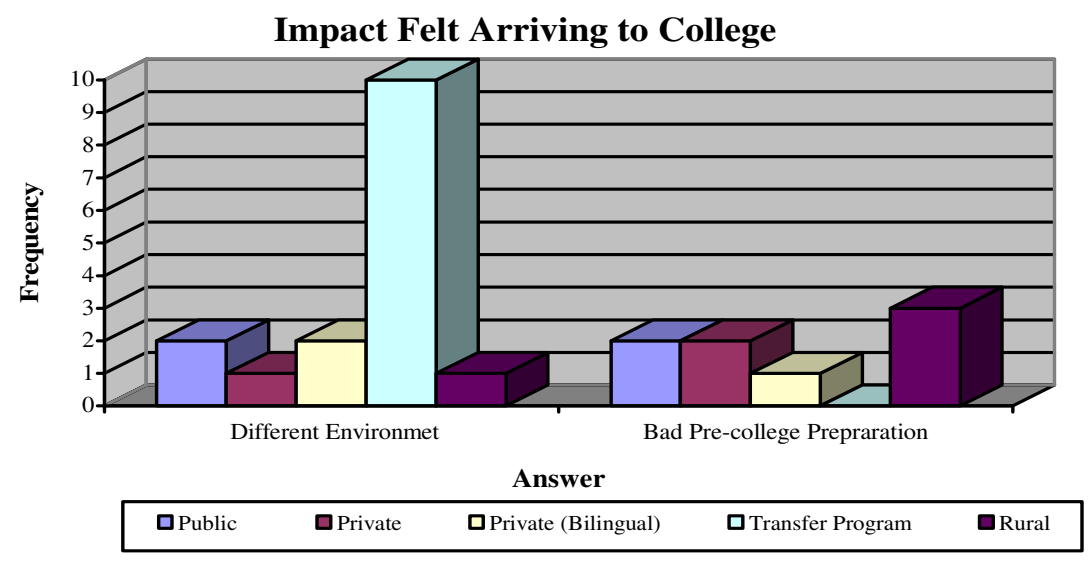

Figure 1: This chart shows the two most relevant answers about the impact they had when coming to college.

\section{HIGH SCHOOL INSTRUCTION}

Instruction in high school turned out to be important for getting the needed development during the university stage and to be successful persons in the future. Throughout this research we could see a trend related to the quality of academic instruction in which half of the interviewed students discovered that they had what they called "a bad high school instruction".

"As a matter of fact I was forced to prepare myself. I made all the effort on my own and if not I was not going to make it" said a student who enter college from a technical public HS.

We noticed most of the students who came from private schools thought they had a good educational background when they arrived at the UPRM, but they actually confronted the same problems of those students who came from public and rural schools (Figure 2). Although private schools provide a diverse curriculum for those students interested in science and math areas, students coming from those expressed the same problems than the rest of the students. This finding was reflected previously in college impact analysis (Figure 1).

Another relevant aspect was critical thinking. Most of the participating students answered that HS instruction didn't promote or encourage students to learn. Even students coming with strong math backgrounds felt that critical thinking was not taught in HS Whenever the problem in the exam did not follow an established procedure they were lost and failed. This aspect was also supported by students who came from different high schools and started at the pre-basic course level in math during the first year in college. 
There are some aspects that students recalled as important to improve HS education, like having specialized schools or school work and better orientation. On the other hand, good teaching strategies were features that some students considered positive during their high school experience. For the improvement of high school education it is necessary that the educational system be modified, providing equal opportunities for all students to choose the curriculum of interest, develop learning methods that help critical thinking and providing advanced math courses, specialized courses and orientation programs.

\section{High School Instruction}

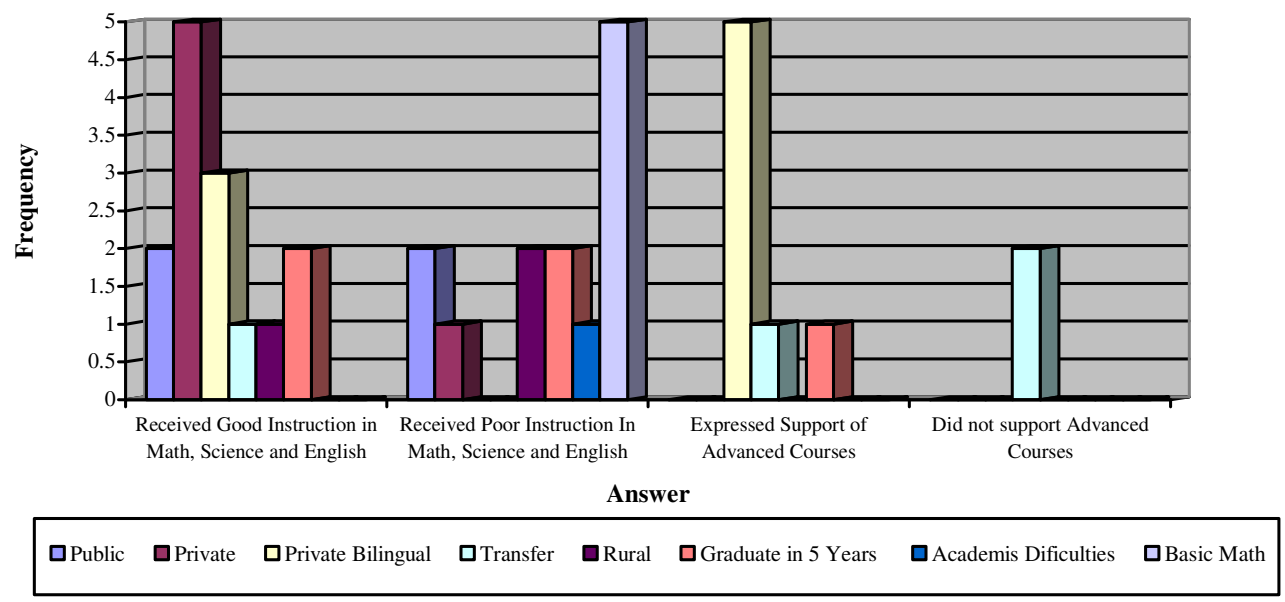

Figure 2: Classification of HS student's instruction

\section{ACAdemic Difficulties Exposed by Students in Probation}

In terms of academic difficulties faced by students, we found six factors that seemed to be the most important. We also identified trends in which students think it may have a significant effect in their academic life. Major trends found were knowledge and failure, getting used to college environment, distractions, time management, and academic instruction and the most important the critical thinking in different areas. In one of these trends we found that students who came from private and public schools think they have the knowledge but did not obtain a good grade or success. Students who have an expectation to graduate in five years (i.e. in the regular time at the UPRM) and students who came from private schools both indicated that the college environment and distractions are some important aspect to consider in academic problem's themes. Otherwise, students who came from private schools think that the problem is that students did not make a good use of their time. There were found that students from different schools did not follow a certain pattern when talking about their academic instruction quality but they classified them in three categories which were poor, good and excellent. This is depicted in Figure 3. 


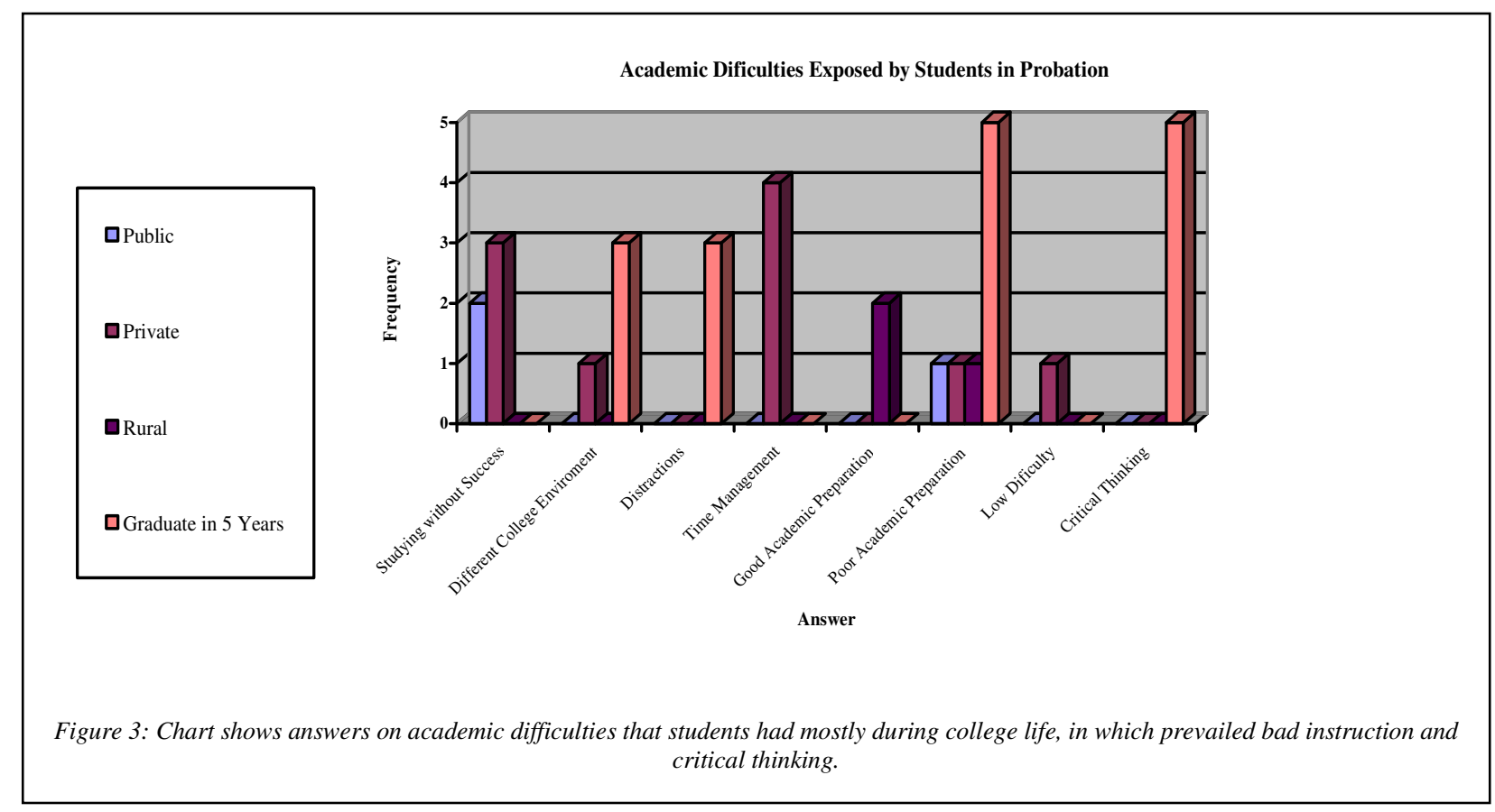

Most of the students interviewed had academic difficulties when entering college. This could be happening because of the HS - College Bridge for all students regardless of the HS of origin or the category into which we grouped them. It is of great concern to know what students need to achieve and accomplish in order to create consciousness among students so they develop a better knowledge and attitude in college.

\section{Areas of Prevalent NeEd for IMProvement IN HS}

During the focus groups we asked students to highlight the most important deficiencies they perceived in their high schools of origin and some critical courses that should be included in the high school curriculum. We also asked them to mention several courses that could help entering freshmen to understand the best approach to tackle academics.

The critical courses were math, English, physics, vocational courses and some general courses (Figure 4). Some students emphasized that the educational system in Puerto Rico should be revised in a way that high school students are encouraged to develop critical thinking using different learning methods. Moreover, it was said that students who enter college do not have the adequate academic instruction at all. This asseveration was supported by most students regardless of their HS of origin. Students coming from public and private schools, transferred students from other campuses, students from rural zones of Puerto Rico and students whom are facing academic difficulties, including students who have a somewhat difficulties in math courses, all agreed with this assessment. Another important factor that students mentioned were the lack of professional guidance and counseling for rural, public and private's high school 
students. Most students had no idea of what IE entitled and about the differences among different engineering disciplines.

We believe that the College of Engineering needs to approach HS teachers and make them aware of the actual situation going on with students. The purpose would be for them to acknowledge the importance and significance of their professions in student's life and the consequences of their teaching methods in college success.

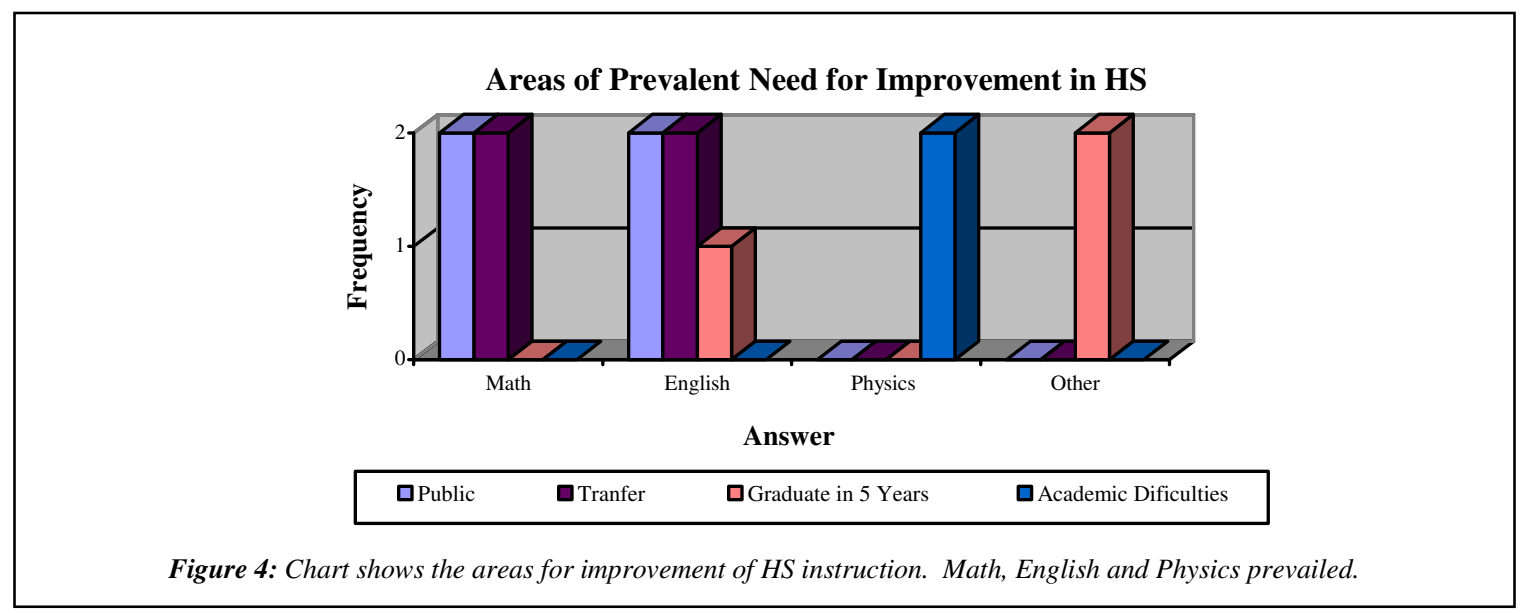

\section{LACK OF ABILITIES}

When a student starts college he or she should be aware of the key to be successful, this is the good habits of study. With this key you can open all doors you want, because besides being important it's very decisive in your career. Interviewed students shown that most of them had poor or didn't had study habits, this tells us that something wrong is happening in high schools that affect the studies in the university. An answer could be those students don't take seriously the studies at high school and are confronting the consequences. Another more intrigue because, perhaps teachers make it easy at high school with basic methods to give classes, and now their lives continue with the same routines but different teaching strategies. Those students with trends of poor habits of study are the ones that had academic difficulties (Figure 5). Another problematic that students had at the UPRM is that they have problems in critical analysis; this is another consequence of the bad or poor education that they received at high school. Also teachers at high school need to be with an excellent or good preparation, because depending of that preparation is going to be the preparation of the students. 


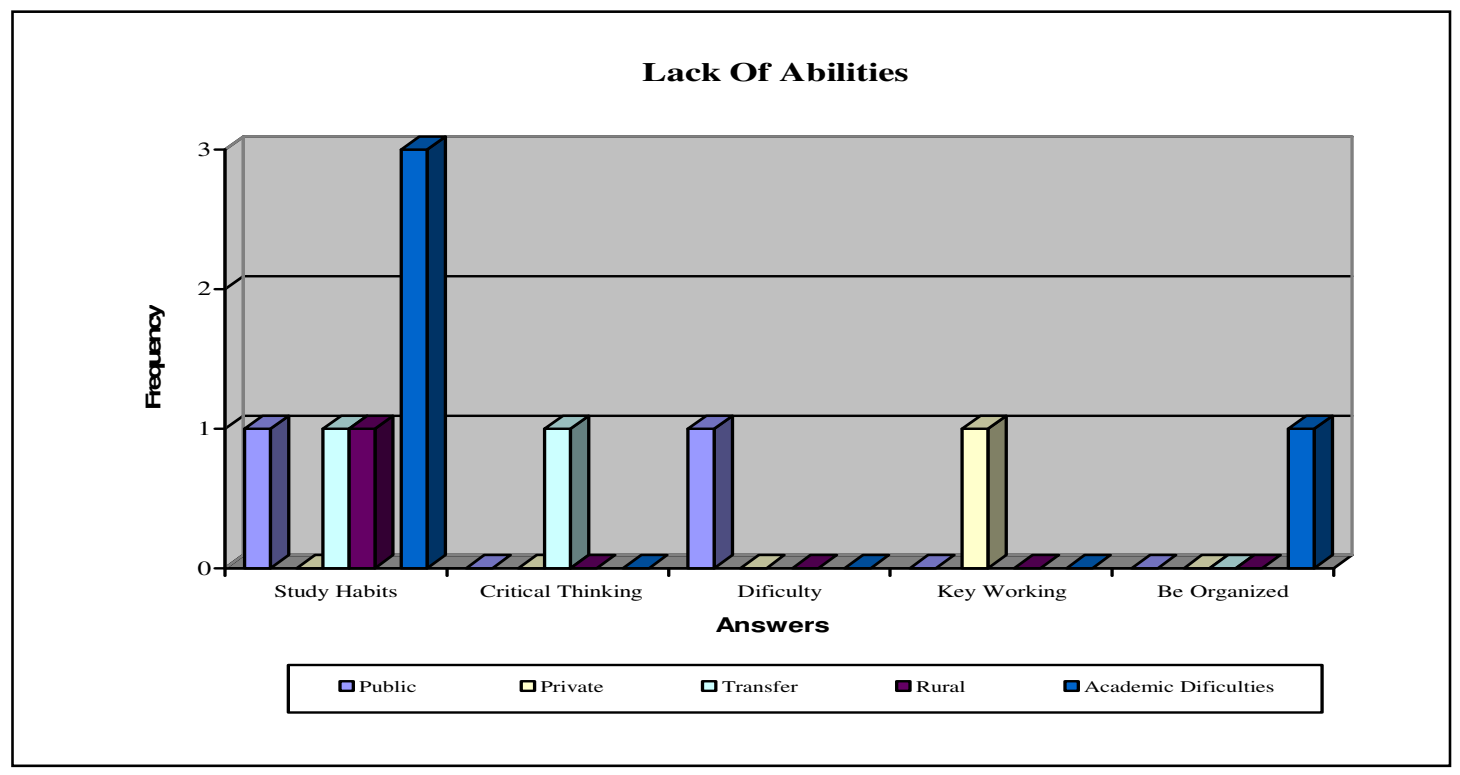

\section{Mathematical AbiLities}

While analyzing the importance given to developing good mathematical abilities, students differed in their answers whereas they came with good or bad math abilities. Students from private and rural schools indicated that while in high school they did not have problems with their math skills; however students from public's schools in urban areas showed a tendency of having poor or bad math abilities. These results showed that private schools have a better degree of high school preparation than the high schools that are supported by the state educational system. Here the main problem is directed to schools that do not prepare students in STEM advanced courses.

\section{Student's FAvorite Courses}

Engineering college students at the UPRM mostly said that one of their favorite's courses in High School was math, no matter from which areas of the island or schools those students came (Figure 6). This is consistent with the expected profile of students aiming at technological careers. Science was the second course that these students preferred. Otherwise, the idea that every IE student likes math it's confirmed because this skill it's vital for solving real life problems. The trends showed that private school students prevail over other types of schools. Private school students consistently expressed that they received a good math education, as it shows at the Lack of Abilities Analysis previously discussed. Students coming from rural zones stated that they received what they considered good math education (Figure 5), however, it was not enough for choosing it as their favorite HS class. If the student doesn't develop their taste for math in HS they can experience academic difficulties in college, like is the case of the students coming from rural areas that had the knowledge but didn't have success because they didn't develop math appreciation and unconsciously they can have a sense that math is irrelevant, when it's not. 


\section{Student's Favorite Courses}

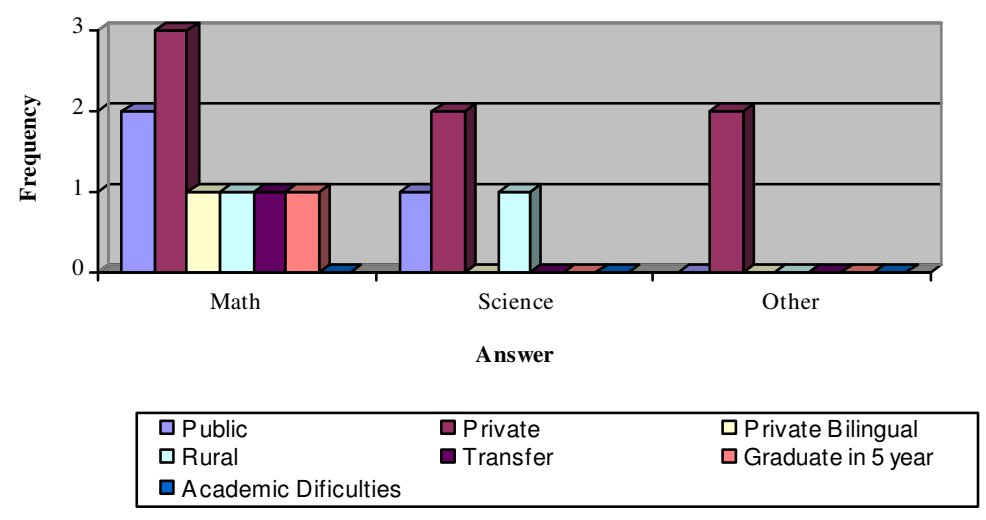

Figure 6: It shows the favorite courses of engineering students in which prevailed the mathematics.

\section{College AcCePtance}

The University of Puerto Rico at Mayaguiez campus (UPRM) is one of the most important universities in the island. This institution is the first college of engineering in the island and the only one in the public university system that offers bachelor of science in engineering degrees. As of today, the UPRM College of Engineering is considered probably the most rigorous. Because of this importance it has a rigorous method of acceptance of students into engineering which makes difficult for the average high school graduate to be accepted. We divided student's answers regarding their expectations of acceptance in three categories, those that were sure to be accepted, those who were not sure and those that had doubts on being accepted. There were not differences in students of different high schools because all of them were sure that they will be accepted (Figure 7). On the other hand, transfer students thought they will not be accepted because they had to reach a good GPA in the campus of origin to be accepted at the UPRM. A small part of rural and private school students had doubts of being accepted. This result could be obtained because some students have problems with their high school GPA and College Board score. 


\section{College Acceptance}

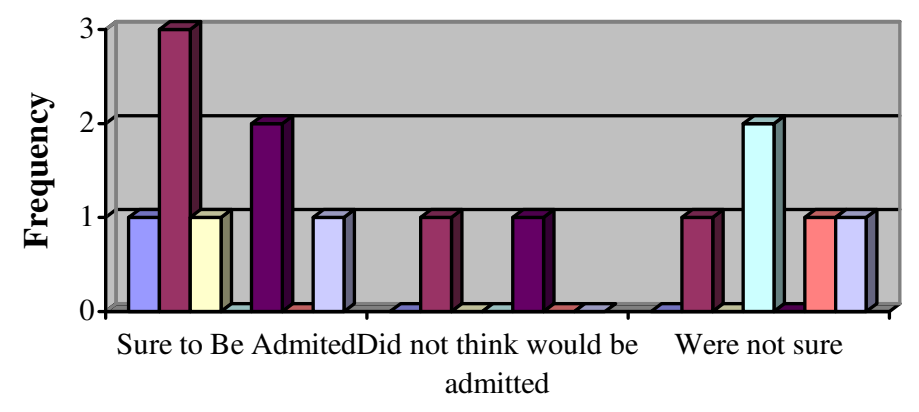

Answer

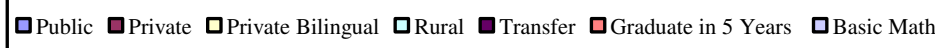

Figure 7: Chart shows the opinion of students about if they thought they will be admitted at UPRM.

\section{Do STUDENTS TALK ABOUT COLLEGE IN HS?}

Students confirmed that in every type of high school people talked about college but especially about UPRM because of its contribution to the engineering field in Puerto Rico. We observed that students who came from high schools located in nearby towns to the university were given more orientation about the benefits of studying at UPRM (Figure 8). In high schools located far from the university the ratio of students being briefed was rather smaller. This could be because students that live far from the university have to face higher economic expenses than students who live nearby and high school's professors did not give enough importance and do not motivate students to study any engineering discipline. Some students faced family pressures to study engineering at UPRM because of the popularity of this institution in Puerto Rico. Other students said familiar pressures did not affect their decision of study engineering and that the hard coursework was considered by them a challenge. 


\section{Do Students Talk About College?}

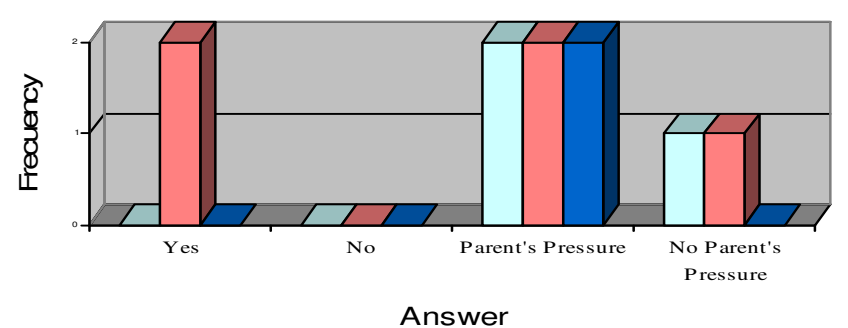

DRural $\square$ Graduate in 5 years $\square$ Academic Dificulties

Figure 8: Most of students said that in their HS they used to talk about College, and their parents influenced the admission to College.

Table 2: Shows the most relevant comments in each group (example: College Impact) with a sub-theme (example: University Environment) of that group and the sub-theme quantities of answers over the total of answers of that specific group. 


\begin{tabular}{|c|c|c|c|}
\hline \multicolumn{4}{|c|}{ TABLE 2: MAIN THEMES OF DISCUSSION } \\
\hline Theme/ Sub-theme & Comments & $\begin{array}{c}\text { Classification of } \\
\text { School }\end{array}$ & $\begin{array}{c}\text { Trends of } \\
\text { Similar } \\
\text { Answers } \\
\end{array}$ \\
\hline \multicolumn{4}{|l|}{ College Impact } \\
\hline $\begin{array}{l}\text { University } \\
\text { Environment }\end{array}$ & $\begin{array}{l}\text { The attitude of the professors towards the } \\
\text { students... They do not care if you are present or } \\
\text { not. For them is only their job. }\end{array}$ & Private (Bilingual) & $13 / 26$ \\
\hline Bad Habits & $\begin{array}{l}\text { The foundation that they gave me in HS was not } \\
\text { enough. Well, when I came to the UPRM, I said: } \\
\text { I'll study the night before the math test and } \\
\text { everything will go fine. Obviously for Calculus it } \\
\text { would not go fine, it could not be done. }\end{array}$ & Public Rural & $6 / 26$ \\
\hline \multicolumn{4}{|c|}{ High School Instruction } \\
\hline Study habits & $\begin{array}{l}\text { In my school basically they gave lots of work, } \\
\text { homework, many tests so you had heavy work and } \\
\text { when you enter college the transition is easier }\end{array}$ & Private (Bilingual) & $18 / 38$ \\
\hline Study habits & $\begin{array}{l}\text { In my school the mathematics and English classes } \\
\text { were excellent. Also, the responsibility, if there } \\
\text { was an assignment for today. it is for today not } \\
\text { for tomorrow. They teach us a greater } \\
\text { responsibility. Here a professor says that a job is } \\
\text { for tomorrow, and it is for tomorrow, so I knew } \\
\text { how to manage my time, because I learn it in HS. }\end{array}$ & Private & $18 / 38$ \\
\hline \multicolumn{4}{|l|}{ Lack of Abilities } \\
\hline Custom of Studies & $\begin{array}{l}\text { The major impact to study because has to } \\
\text {...discipline. Because we in HS had a simple } \\
\text { method of study that we need to change when we } \\
\text { come to the UPRM. Because in high school people } \\
\text { can study two days before the test, as a fact it is } \\
\text { just memorizing. When you come to College you } \\
\text { need to understand the concepts so you can apply } \\
\text { them on the exam. }\end{array}$ & Rural & $7 / 10$ \\
\hline Custom of Studies & $\begin{array}{l}\text { If you don't create good habits of study you can } \\
\text { find professors that give a mid-term in the middle } \\
\text { of the semester, and a final one; and if you don't } \\
\text { have study habits with so much material, you are } \\
\text { going to drop out. }\end{array}$ & $\begin{array}{l}\text { Academic } \\
\text { Difficulties }\end{array}$ & $7 / 10$ \\
\hline \multicolumn{4}{|l|}{ Mathematical Abilities } \\
\hline Good math Ability & I did not have an A, but I learned a lot (in $H S$ ) & Private & $11 / 15$ \\
\hline Poor math Ability & $\begin{array}{l}\text { I got here with what I believed was good } \\
\text { knowledge and once in college, I got depressed, it } \\
\text { is a source of great frustration. }\end{array}$ & $\begin{array}{l}\text { Academic } \\
\text { Difficulties }\end{array}$ & $4 / 15$ \\
\hline \multicolumn{4}{|c|}{ Student's Favorite Courses } \\
\hline Math & Mathematics... until I got to the UPRM. & Rural & $9 / 14$ \\
\hline Sciences & $\begin{array}{l}\text { I would have liked to take a physics class (in HS) } \\
\text { s. I took chemistry on eleventh grade, but } \\
\text { everything was very basic. I met friends that took } \\
\text { physics with advanced chemistry in twelfth grade } \\
\text { at HS, and it went easier here at the UPRM. }\end{array}$ & Private & $4 / 14$ \\
\hline
\end{tabular}




\begin{tabular}{|c|c|c|c|}
\hline \multicolumn{4}{|c|}{ Hope for College Acceptance } \\
\hline Yes & $\begin{array}{l}\text { Well, I expected yes, because I was preparing to } \\
\text { enter the UPRM since I begun HS. I knew that I } \\
\text { was going to study at the UPRM, but without } \\
\text { knowing yet what to study. I only knew I ought to } \\
\text { study here, because I live nearby. But people told } \\
\text { me that it was very hard to enter, so during HS I } \\
\text { was preparing, and I set it as a goal to have good } \\
\text { academic standing. }\end{array}$ & Private & $10 / 17$ \\
\hline Maybe & $\begin{array}{l}\text { I did not have a good counselor that explains me } \\
\text { the requirements necessaries to enter to college. I } \\
\text { applied to Computer Engineering and but I didn't } \\
\text { accomplish with one of the requirements, and I } \\
\text { verify the option to another college and I make a } \\
\text { reclassification to enter to Industrial Engineering. }\end{array}$ & Private & $5 / 17$ \\
\hline \multicolumn{4}{|c|}{ Did students talk about engineering in HS? } \\
\hline Yes, was mentioned & $\begin{array}{l}\text { My mathematics professor motivated us, she gave } \\
\text { us full support (to apply to the UPRM). }\end{array}$ & Public & $8 / 28$ \\
\hline $\begin{array}{l}\text { Parents/ Family } \\
\text { Pressure }\end{array}$ & $\begin{array}{l}\text { Maybe I felt an obligation with my mother, } \\
\text { because she sacrificed many things for me. I'm not } \\
\text { from Puerto Rico, and when we came here, she } \\
\text { left everything back in her country. And I would } \\
\text { like to pay all the sacrifices she made for me, } \\
\text { making a good preparation in a career. Studying } \\
\text { at the UPRM. }\end{array}$ & $\begin{array}{l}\text { Academic } \\
\text { Difficulties }\end{array}$ & $4 / 28$ \\
\hline \multicolumn{4}{|c|}{ Difficulties faced (academically) } \\
\hline $\begin{array}{l}\text { Study, and study, and } \\
\text { never have success }\end{array}$ & $\begin{array}{l}\text { In my case, (what surprised me the most)..the } \\
\text { mathematics, I entered in pre-calculus II and this } \\
\text { surprised me because I knew the material and in } \\
\text { the exams I am not able to get good grades. }\end{array}$ & Private & $5 / 29$ \\
\hline $\begin{array}{l}\text { Poor Pre-College } \\
\text { Preparation }\end{array}$ & $\begin{array}{l}\text { In HS you learn concepts and utilize methods that } \\
\text { don't help in the university. }\end{array}$ & Public & $9 / 29$ \\
\hline \multicolumn{4}{|c|}{ Recommendations to change things in HS } \\
\hline $\begin{array}{l}\text { Deficiencies in } \\
\text { Courses }\end{array}$ & $\begin{array}{l}\text { In some High Schools the advanced math doesn't } \\
\text { help us, because the teachers don't follow the } \\
\text { supposed strict coursework and gave us simple } \\
\text { problems. }\end{array}$ & Public & $21 / 33$ \\
\hline $\begin{array}{l}\text { Deficiencies in } \\
\text { Courses }\end{array}$ & $\begin{array}{l}\text { I think that the Department of Education should } \\
\text { classify students according to their career goals. } \\
\text { They should figure out how to help them with a } \\
\text { certain program. For example, if you are going to } \\
\text { study engineering, give emphasis to math, science, } \\
\text { physics, and advanced courses that will help in } \\
\text { college. And if you are going to study in another } \\
\text { area, give the respective courses in such area. } \\
\text { That will be the way that for you to select the } \\
\text { appropriate courses depending of the future } \\
\text { career that you want to pursue... }\end{array}$ & $\begin{array}{l}\text { Will Graduate in } 5 \\
\text { years }\end{array}$ & $21 / 33$ \\
\hline \multicolumn{4}{|c|}{ Mistakes and good practices of HS teachers } \\
\hline Poor Teaching & $\begin{array}{l}\text { In nothing, no one prepared me. In math, I did not } \\
\text { take trigonometry with algebra at High School. I } \\
\text { was placed in Pre-calculus and I was like, "Oh my } \\
\text { God, what's this!" For succeeding in the class I } \\
\text { had to study from the book by myself. If I have not }\end{array}$ & Pre-Basic Courses & $4 / 10$ \\
\hline
\end{tabular}




\begin{tabular}{|l|l|l|l|}
\hline & done that I could not pass the class. & \\
\hline Good Teaching & $\begin{array}{l}\text { At my school math and English were excellent. } \\
\text { Equally excellent was the responsibility, if there } \\
\text { were an assignment for today, it was actually for } \\
\text { today, there were no spaces for being late. Here it } \\
\text { is the same, if a professor wants an assignment for } \\
\text { tomorrow we had to do it for tomorrow. We were } \\
\text { taught time management. }\end{array}$ & Private \\
\hline Misconceptions that prevent high school students when applying to be accepted into engineering \\
\hline
\end{tabular} \begin{tabular}{l}
$\begin{array}{l}\text { Well, I think that each person, sometimes is afraid } \\
\text { of what he says, how many students better than } \\
\text { would be. Systems are different and maybe you } \\
\text { feel like you're in a competitive level. }\end{array}$ \\
\hline
\end{tabular}

\section{V-CONCLUSION}

This research sought to sense the feelings, attitudes and voices of students in IE, something which other data collection methods could never explain, due to a direct and consistent link among interviewer and interviewee. Many topics were studied and related in order to identify improvement opportunities in the HS - College Bridge for engineering students and different explanations raised to eradicate them. It is of great significance and importance to create compete engineering professionals with a high intellectual knowledge and attitude.

Through this study we could identify which were the factors that affected the academic life of students and prevented them to achieve success. Initially we stated the hypothesis that the nature of and /or location of the school had an impact on education quality but we were really mistaken. Basically the problem is general to all HS, independently if they are private or public, and these problems will have impact in college. There are several factors but the most outstanding ones require urgent intervention and are: poor instruction in HS, which encompasses both math deficiencies, but also lack of demands from HS teachers as to instill better study habits and total lack of critical thinking skills. In addition, poor teaching strategies in HS and lack of preparation or information about what to expect in college from both students and teachers. HS teachers in PR tend to be nurturing, and the reality in college is much different, and comes as a surprise for freshmen. Particularly, instructors for freshmen math remedial classes tend to be foreign graduate students with no patience, commitment or sympathy for the incoming student. However, even students from good high schools entering Calculus I directly failed if they had poor study habits, and most students identified time management deficiencies as being an issue.

It is frequently believed that private school students have a better instruction but we clearly found no difference between these two categories. Private school students believed they were well-prepared and had a good background education in comparison to public school students, but the academic difficulties faced after entering engineering in their freshmen year were the same. No matter from which school students come from, schools seem not to adequately prepare students to begin engineering studies. Even students that alleged to be prepared and some who took advanced courses also confronted academic difficulties, whereas they came from public or private school.

This study sought to identify what were the prevailing trends in the focus groups. The one factor that we observed came out frequently across all groups was the perception of students that 
they arrive to college missing the development of critical thinking skills. The way of solving problems in a methodological way does not always result in being effective problem solvers because it preserves a superficial way of learning. College students need to broad and improve the skill of thinking ("critical thinking") because it is the only way how they can resolve real life situations without searching for a procedure in a book. The participating students faced challenging courses in college, for which learning a procedure was not enough to comprehend the class.

Students said that HS teachers were full of procedures to follow where teachers go along with you in each step of the subject. In general, this hurt student performance at the university since in engineering the best method was total opposite. Professors taught within a standard time without taking into consideration if the student actually comprehends the material. It fits to indicate that it is of great importance to emphasize a comparison of the theory versus our findings. In the literature we found various articles discussing issues such as freshman enrollments, intellectual development, engineering student success, prolonging graduation that discussed the different faces of the student in the university life. Most had a point of agreement with respect to HS of origin. They mentioned that in general HS education does not have an adequate level of education to prepare its students to the challenges that wraps the university.

Our study using the focus group approach confirms the literature previously established, since the comments that excelled the most illustrated deficiencies in HS that triggered academic difficulties. A recent article on "Intellectual Development" ${ }^{3}$ argues that students enter the lowest levels of learning and that in the great majority of times when obtaining the degree in engineering they fail to reach a deep intellectual and creative development. At the UPRM happens exactly the opposite, although students enter with serious academic deficiencies, the institution complies with its mission of creating good capable engineers. Anyhow, changes and improvements must be made in order to reduce problems and prevent students from taking extra years of study because of failing courses, for example.

Although the Department of Education in Puerto Rico seems to be aware of the situation they are not taking corrective actions in HS curriculum and neither in the way of teaching. Our research conclusions and recommendations are going to be published in order to make everyone attentive and responsive in this matter. Hence, a curricular revision of the HS educational system targeting STEM careers as well as instruction techniques at the university is encouraged to be applied. Specifically, to create workshops targeting HS teachers to instill better attitudes, learning techniques and preparation towards to have HS students wholly instructed.

On the other hand, the Industrial Engineering Department is currently analyzing areas of opportunity to increase students' success probabilities and reducing attrition. They are currently working on promoting and advertising the field while visiting and presenting it in diverse settings. Also, IE faculty is examining the current curriculum to enhance it in a way that students get enough skills in their freshman and sophomore years to have a successful performance further in their specialty courses. In order to fully support the UPRM IE Department efforts, conclusions and data from this research will be provided. This research will serve as a guide for faculty to actually identify the areas of opportunity that may be implemented. Also, it is expected that this research be the beginning of many studies conducted 
in Puerto Rico to entirely contribute to evolve education into one which takes into consideration the educational goals of the HS student. Further research incorporating what the engineering profession already know about how young people learn engineering to the findings of this study will be used to create critical thinking materials and other tools, and train teachers The use of these results to be applied in other Puerto Rican universities facing our same issues is also desired.

\section{REFERENCES}

${ }^{1}$ Richard W. Heckel, "Engineering Freshmen Enrollments: Critical and Non-Critical Factors", Journal of Engineering Education, January, 1996, pp 15-21

${ }^{2}$ Merry Besterfield-Sacre, Cynthia J. Atman, Larry J. Shuman, "Characteristic of Freshmen Engineering Students: Models for Determining Student Attrition Engineering", Journal of Engineering Education, April, 1997, pp 139-149

${ }^{3}$ Felder, Richard M, Brent, Rebecca, "Intellectual Development of Science and Engineering Students. Part 2: Teaching to Promote Growth", Journal of Engineering Education, October, 2004

${ }^{4}$ Marna Zinatelli, Mark A. Dude, "Engineering” Student Success: How does it happen and Who is Responsible?", Journal of Engineering Education, April, 1999, pp 149-152

${ }^{5}$ Guili Zhang, Timothy J. Anderson, Matthew Ohland, Brian R. Thorndyke, "Identifying factors influencing Engineering Student Graduation: A Longitudinal and Cross-Institutional Study", Journal of Engineering Education, October, 2004, pp 313-320

${ }^{6}$ www.oiip.uprm.edu, accessed on 01/14/07

${ }^{7}$ Van A., Watford B., Medina-Borja A. The Use of Focus Groups for Minority Engineering Program Assessment 